\title{
A sustainability evaluation framework for Science and Technology Institutes: an international comparative analysis
}

\author{
Rafael Gustavo de Lima ${ }^{a}$, , Hoyêdo Nunes Lins ${ }^{a}$, Elisete Dahmer Pfitscher ${ }^{a}$, \\ Jéssica Garcia ${ }^{\text {b }}$, Alek Suni ${ }^{\text {b }}$, José Baltazar Salgueirinho Osório de Andrade Guerra ${ }^{\text {b }}$, \\ Finati Caroline Renata Delle ${ }^{\mathrm{c}}$ \\ a Universidade Federal de Santa Catarina, Florianópolis, Santa Catarina, Brazil \\ b Universidade do Sul de Santa Catarina, Florianópolis, Santa Catarina, Brazil \\ c Universidade Estadual Paulista Júlio de Mesquita Filho, UNESP, São Paulo, Brazil
}

\section{A R T I C L E I N F O}

\section{Article history:}

Received 19 September 2015

Received in revised form

1 March 2016

Accepted 4 March 2016

Available online 25 March 2016

\section{Keywords:}

Science and Technology Institutes

Sustainability

Sustainability evaluation framework

\begin{abstract}
A B S T R A C T
The concerns with the spread of sustainable practices in Higher Education Institutions are growing considerably due to the reach of these institutions in society and in local communities. This research develops and applies a framework that takes into account the social, economic and environmental concerns to evaluate to what extent Science and Technology Institutes are contributing to the spread of sustainable practices. It combines the measurement system from the Global Reporting Initiative, Public Administration Environmental Agenda and International Sustainable Campus Network guidelines. This research therefore highlights Science and Technology Institutes as a form of participatory management in sustainable practices that can be replicated in society and beyond campuses. From a questionnaire using the Sustainability Evaluation International Framework applied to Science and Technology Institutes, results show that the international Science and Technology Institutes selected (Massachusetts Institute of Technology and Swiss Federal Institute of Technology Zurich) are characterized as "excellent", and three Brazilian institutions' performances by the same metric are evaluated as "regular".
\end{abstract}

(c) 2016 Elsevier Ltd. All rights reserved.

\section{Introduction}

The theme of sustainable development and sustainability started through a series of international studies from the midtwentieth century (Louette, 2007). Currently, international and national efforts by governments and companies around the world are reflected by concerns over the use of natural resources. Regarding the nexus between higher education and sustainable development, Beynaghi et al. (2014) claim that it has been gradually growing since 1972, creating a new trend. 'Sustainable development issues should be linked with stakeholders and society interests, integrated with the basic functions of universities:

\footnotetext{
* Corresponding author. Servidão Alfredo Silva, 76 88040-415 Florianópolis, Santa Catarina, Brazil. Tel.: +55 4899328681 .

E-mail addresses: Rafael.lima@ufsc.br (R. Gustavo de Lima), hoyedo.lins@ufsc.br (H.N. Lins), elisete.dahmer@ufsc.br (E.D. Pfitscher), Jessica.sgarcia@outlook.com (J. Garcia), alekwsuni@gmail.com (A. Suni), baltazar.guerra@unisul.br (J.B. Salgueirinho Osório de Andrade Guerra), Caroline.finati@gmail.com (F. Caroline Renata Delle).
}

education, research and university management activities' (Katiliute and Daunoriene, 2015, p. 866).

The question of how to measure sustainability is introduced by the discussion on how to measure development as a whole. Rather new, the academic ability to use social indexes in general gained "scientific body" in the middle of the 1960s (Jannuzzi, 2008). Development, understood solely as economic growth, needed adaptations that would reflect more than simply total gross domestic product (GDP). It was therefore necessary to assess societies' social welfare (Jannuzzi, 2008).

Since then, research departments have been created specifically to produce systematic reports on the social situation where they were inserted. They began to provide governments around the world with information on where and why investments were necessary in certain sectors, rather than others (Jannuzzi, 2008). Van Bellen and Michael (2006) affirm that the assessment of sustainability must have a measure sufficiently extensive to grasp factors related to sustainability. "More and more often, availability of data, i.e. obtaining the value of sustainability indicators, is not a problem. The main difficulties relate to selection, interpretation and the use of indicators" (Moldan et al., 2012, p. 7). Sustainability 
indicators can be used to simplify and quantify information for use by decision-makers and the public (Cole, 2003; Chambers et al., 2000; Rodenburg, 1995).

Van Bellen and Michael (2006) explain that the construction of indexes that enable the measurement of sustainability must link the temporal gaps past/present/future, always having in mind its practical utility in decision making, when making policy decisions and evaluating degrees of success. Olszak (2012) brings attention to the inadequacy of attempting to measure sustainability in universities, since most of the studies only focus on the environmental pillar while they should take into account the economic and social pillars as well. Moldavska and Welo (2015) go further and state that these three pillars should be addressed equally when building an assessment tool.

The promotion of sustainability within the campus infrastructure and operational activities could serve as examples for behaviors and be spread to other sectors of the society (Posner and Stuart, 2013; Jenks-Jay, 2003). Moreover, Shriberg (2002) argues that one of the shortcomings in sustainability evaluation is the lack of assessment tools that provide mechanisms for comparing campus efforts against other institutions or national/international averages. Motivated by this gap in the current assessment tools, this article aims to analyze to what extent are the Science and Technology Institutes contributing to the spread of sustainable practices, making a comparison between MIT, ETH-Zurich and the STIs of southern Brazil and verifying, through an evaluation model, the selected STIs' contributions in the social, environmental and economic impact of their activities.

To achieve these objectives, this research combines the international guidelines from the Global Reporting Initiative (GRI), the principles from the International Sustainable Campus Network (ISCN), and the guidelines from the Public Administration Environmental Agenda (A3P) from Brazil.

\section{Literature review}

It is important to understand the extent to which STIs are protagonists in the debate and in developing new institutional standards since they are considered to be microcosms of the larger community and therefore important in demonstrating environmental responsibility (Katiliute et al., 2014). According to Alshuwaikhat and Abubakar (2008) their managers are responsible for the impacts the activities and operations of universities have on the environment.

Furthermore, universities are similar to small cities and therefore, the students can be considered as urban agents (Collins, 2010). It is believed that these institutes are able to explore and combine new sources of natural/material resources, driving markets, governments and civil society to continuously improve their methods and their everyday solutions. According to Sikka (1998, p. 45), "science and technology are among the vital components of national economic development, providing a basis for innovation, productivity, growth, and maintaining international industrial competitiveness." Additionally, "a school campus is an urban space configuration which can provide a foundation for promoting the sustainable development of a city; it can serve as a pioneer, demonstrator and promoter" (Ho et al., 2014, p. 461).

In order to achieve sustainability in a higher education institution (HEI), decision makers need to minimize the negative environmental, economic, societal, and health effects generated in the use of their resources (Velazquez et al., 2006). One of the major challenges is the fact that universities tend to be traditional and resist change (Lozano et al., 2013; Ferrer-Balas et al., 2010; Elton, 2003). For this reason, incorporating sustainability in HEIs presents itself as a challenge in educational and operational dimensions, and it also should take into account the external community (FerrerBalas et al., 2010; Cortese, 2003).

To build an evaluation framework, this research focuses on analyzing the economic, environmental and social/institutional aspects of selected STIs, with the purpose of highlighting the best performances so that they can be replicated by other institutions and society. Evaluating the various activities regarding sustainability in a HEIs campus can be a simple task and is needed in order to be a pillar of strength for achieving a sustainable environment (Bantanur et al., 2015; Townsend and Barrett, 2015). Both universities and society benefit from improving campus sustainability since it provide benefits to the community and to the owners of the facilities (Faghihi et al., 2015).

When it comes to sustainability reporting, the main focus is to evaluate social, economic and environmental aspects of an institution and share information about sustainability efforts and progress to stakeholders (Hamann, 2003; Lozano and Huisingh, 2011). However, the task of evaluating the incorporation of sustainability initiatives within a HEIs is still in progress due to the small number of school campuses involved and the low quality of reporting, since most of the tools used have the need to be redesigned for a school campus (Lozano, 2006; Alonso-Almeida et al., 2015).

For Yarime and Tanaka (2012), most of the assessment tools are focused on issues like energy consumption, water/sewage, solid waste management and transportation. Assessing physical operations can be easier because of the quantitative data arising from these activities, making for simpler comparison with the same activities in other institutions (Yarime and Tanaka, 2012; Lozano, 2006). The development of a cross-institutional assessment tool could help identify best practices, share experiences and methods and provide a directional tool to measure progress toward the concept of a sustainable campus (Shriberg, 2002).

According to Klein-Banai and Theis (2013), learning from other HEIs could provide a solution for the global issues involving environmental problems. Additionally, it is believed that institutional support is most important in integrating sustainability into management education (Figueiro and Raufflet, 2015; Barth, 2013; Lozano, 2010). Therefore, the role of an institution's leaders is fundamental to supporting sustainability-minded changes.

\subsection{Guidelines}

Considering the option of using the measures/indexes from the Global Reporting Initiative (GRI), International Sustainable Campus Network (ISCN), the Public Administration Environmental Agenda (A3P), and the methodology of the Environmental Management Accounting System (SICOGEA), it is necessary to understand the ideas that guide such tools.

The Global Reporting Initiative (GRI, 2013a) produces internationally accepted guidelines for sustainability reports around the world. "GRI is a reporting guideline but also a system that can provide certification of the reporting process, using several indicators to assess and communicate the sustainability of organisations" (Domingues et al., 2015). According to Menichini and Rosati (2014), the GRI ensures transparency and completeness of released data, and therefore, its standard is the most widely used framework to support institutions in its sustainability reporting. "As a network-based organization it developed its reporting framework in collaboration with stakeholders from business, government, labor, and professional groups in order to ensure credibility and relevance" (Wilburn and Wilburn, 2013, p. 65).

The data used were collected from the last update of the GRI guidelines (G4), outlining the areas and subareas of action in their indexes, so it is possible to observe how the GRI categorizes the 
Table 1

A3P guidelines - Environmental Agenda in Public Administration.

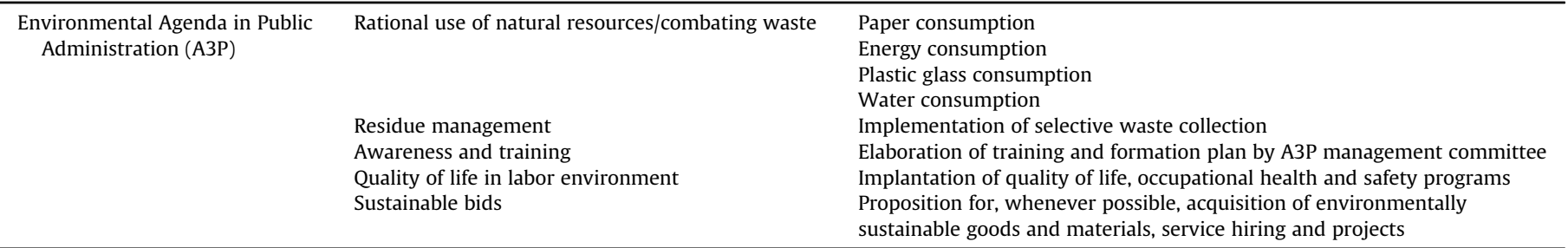

Source: MMA - A3P, 2009.

measurement of the sustainability of an organization. That is to say, in general terms, that for one of the most used international tools to evaluate sustainability, its aspect accommodates the themes that are relevant to the sustainability of their operations. The guidelines are divided in two categories: Economic and Environmental. The first approaches: Economic Performance; Presence in the Market; Indirect Economic Impacts and Purchasing Practices. The second brings features such as: Materials; Energy; Water; Biodiversity; Emissions; Effluents and Waste; Products and Services; Conformity; Transportation; General; Environmental Evaluation of Suppliers and Mechanisms of Complaints Related to Environmental Impacts.

For this research, the operationalization of the GRI indexes enables the establishment of internationally standardized metrics to measure the economic, social and environmental dimensions of sustainability in Science and Technology Institutes (STIs), as already occurs with the Swiss Federal Institute of Technology Zurich - ETHZurich.

Lastly, the guidelines that compose Brazilian concerns with sustainability through the A3P actions will also be presented, which also mesh with the GRI's aims.

The evaluation of sustainability at the STIs, besides gathering the guidelines suggested internationally by GRI, incorporates questions related to the A3P instructions and will follow the proposition in Table 1:

It is worth remembering that, in a way, Global Report Institute is concerned with Environmental Agenda in Public Administration, considering the scope of each tool. While A3P is based on national concerns, GRI evaluates sustainability in a broader international sense, aiming to be used by a variety of different entities (NGOs, companies, governments, etc.). However, for this research, the use of Environmental Agenda in Public Administration, reveals the relevance the authors intend to give to the investigation of Brazilians Science and Technology Institutes, such as the Federal Institute of Santa Catarina, the Federal Institute of Rio Grande do Sul and the Federal Institute of Paraná.

Another source of contribution for the research is the International Sustainable Campus Network - ISCN, which today comprises 77 educational institutions on five continents, from universities, STIs, polytechnic schools to HEIs in general.

ISCN offers three basic principles disseminated within the debate that considers the sustainability on campuses: construction and its sustainable impacts; planning on campus; and integration of research, teaching and installations, namely: Buildings and their sustainability impacts; Campus-wide planning and target setting; and Integration of research, teaching, facilities and outreach (ISCN, 2013).

\section{Methods}

The chosen STIs were the Massachusetts Institute of Technology - MIT, in the United States and the Swiss Federal Institute of
Technology Zurich - ETH-Zurich, in Switzerland, because of the ability to use very recently collected data, ${ }^{1}$ found in the ISCN and GRI publications. Furthermore, the choice of two international STIs is justified, because each is characterized by internationally recognized participation in sustainability activities on campus, in addition to their special representation in the ISCN Directory.

The evaluation framework is constructed by taking into consideration the combination of the international guidelines found in the United Nations Sustainable Development Knowledge Platform. This includes contributions given by the GRI, the principles of the ISCN, and the A3P, from Brazil. The challenge in integrating and synthesizing different tools and indicators while also stating the importance of combining them in a meaningful manner rather than using a single tool that might not capture all the aspects needed to build a strong framework is recognized and supported by research (de Vries and Petersen, 2009; Nourry, 2008; Ness et al., 2007).

Another reason to use an integrated sustainability assessment is that it can be conducted both at a micro or macro level (Streimikiene et al., 2009). However, there is still discussion about the choice of tool combinations. According to the literature, the objective is addressing tool combinations and tool usage in connection with actual policy-supporting integrated assessment processes, following logical, consistent procedural steps (Sala et al., 2015; Gasparatos and Scolobig, 2012; de Ridder et al., 2007).

This paper also includes a case study based on the Brazilian South, aiming to apply these research standards at the regional level, in order to evaluate the concerns of local institutions about the internationally disseminated guidelines. The following data collected from the Federal Education, Science and Technology Institutes from the states of Rio Grande do Sul (IFRS), Santa Catarina (IFSC) and Paraná (IFPR) therefore seeks to draw comparisons between these institutions and their foreign STI counterparts. It was not possible to analyze a Brazilian entity that is part of ISCN because, until the date that this research was conducted, in June 2014, there was no Brazilian entity registered in the ISCN. The situation changed with the recent entry of University of Rio de Janeiro at a later date. Moreover, the idea of evaluating a Brazilian entity is justified because the national STIs are not as connected to the higher education sustainability networks elsewhere in the world and Brazilian participation in this field is very limited.

The foreign STIs are analyzed through information that respond to the concepts proposed by the evaluation model. The methodology for the Brazilian STIs (IFSC, 2014; IFPR, 2014; IFRS, 2014) provides the opportunity to collect the data from primary sources through online questionnaires that discuss the questions raised by the evaluation model.

\footnotetext{
1 The most recent publications of the STIs selected are from the period between 2010 and 2014
} 
Table 2

Environmental Management Accounting System's steps - SICOGEA.

\begin{tabular}{|c|c|c|}
\hline Steps & Description & Observation \\
\hline STEP 01 & Integration of the productive chain & Identify the production process, the main needs and the likelihood of harming the environment. \\
\hline STEP 02 & Ecologic control management & Verify which sectors of the organization may be causing environmental impacts. \\
\hline STEP 03 & $\begin{array}{l}\text { Accounting management and } \\
\text { environmental controllership }\end{array}$ & $\begin{array}{l}\text { Estimate the economic, financial and operational aspects, aiming to obtain new forms of contributing } \\
\text { with the environment. }\end{array}$ \\
\hline
\end{tabular}

Source: Pfitscher, 2004.

To reach the paper's target framework with structured questions from Pfitscher's (2004) study, the application and calculations stem from the third generation SICOGEA contributions. Pfitscher's (2004) work discussed the evolution of the Environmental Impact Aspects Management method, called GAIA, created by Lerípio (2001).

According to Pfitscher (2004), Environmental Management Accounting System's goal is to operationalize the analysis of organizations' sustainability using social, environmental and economic indexes, to identify the greatest environmental impacts. Pfitscher (2004) divided SICOGEA in three steps, as shown in Table 2:

Starting with SICOGEA, the model's twofold development is evident. The first came from Nunes' (2010) improvement of the evaluation framework, which became known as second generation SICOGEA. The author reshaped the model focusing on two methods, GAIA and SICOGEA, to check for strong and weak points in a process of continuous methodological improvement, eventually suggesting a new methodology.

Uhlmann (2011), after analyzing the second generation SICOGEA method and its applications, formulated the third generation SICOGEA. In this version, it was not possible to observe significant structural changes in the methodology, which would point to changes in the methodology used to calculate the environmental sustainability indexes. However, third generation SICOGEA presented an inclusion and reorganization of action items, with an eye toward the impact of outcomes and the ease of a system's application. Taking these contributions into consideration, Pieri et al. (2011) determined an evaluation format to examine STIs in order to establish a metric able to put the information together in a table, and ascertain a level of sustainability for each of the criteria suggested.

It is therefore possible to apply the GRI international guidelines with SICOGEA application methodology, so as to propose a new sustainability evaluation framework for STIs that emphasizes the quantitative value of a sustainability rating that the GRI methodology lacks in its indexes and reporting format.

Still, this research has limitations. The evaluation of only one sample of STIs around the world does not allow the construction of an overall picture showing the contribution of these institutions to the spread of sustainable practices globally. However, it is possible to show the extend of contributions of two renowned international institutions (MIT, ETH-Zurich) and Federal Institutes of southern Brazil, making a comparison between them. In addition, another limitation is the complication of the framework's construction which, even when guided by international instruments (GRI, ISCN, A3P), still includes some measure of researcher subjectivity in its framework (SICOGEA).

\subsection{Construction of the sustainability evaluation framework: SEIF/} STI

The model used for the sustainability evaluation of the STIs selected for this research, Sustainability Evaluation International Framework applied to Science and Technology Institutes (SEIF/STI), will use Environmental Management Accounting System's third generation framework. The goal of the system is to manage the socio-economic-environmental aspects of organizations' resources and processes, to help managers' decision making to ensure STI sustainability.

To organize the information, the SEIF/STI is divided into three steps: Economic, Environmental and Social/Institutional. Table 3 presents them through categories originating from GRI, A3P and ISCN. As a result, it becomes possible to understand how the system is structured to measure/calculate quantitatively the sustainability of the STIs involved:

In summary, the evaluation format to be used by the SEIF/STI settles a metric that is capable of putting the information together in one table, and indicates a level of sustainability for each of the proposed indexes, according to the SICOGEA third generation methodology. Table 4 shows the structure of the model in its first Step, called the Environmental Index, referring to "energy":

The international guidelines originating from GRI and ISCN and A3P can be applied to the STIs involved, combined with the third generation SICOGEA methodology, offering a new framework of sustainability evaluation for the STIs - SEIF/STI - which emphasizes the quantitative degree of sustainability. Such values are useful to corroborate whether the Scientific and Technological Institutes selected contribute toward a broader international sustainability regime.

Overall, the model presents 301 questions posed to certain STIs' leaders, considering their responsibilities in the scope of direction and management. The questions were divided into four parts and sent online, in the following categories: questions of Economic Performance; questions of Environmental Performance; and questions of Social Performance (GRI/A3P/ISCN).

Furthermore, for each question it is possible to measure the degree of sustainability in indexes ranging from 0 to $100 \%$; they produce outcomes which vary from "excellent" to "terrible", as seen below. It is also possible to invert a question, where the minimum ( $0 \%)$ would correspond to "excellent", although an "S" must be inserted in the "reverse answer" column to indicate that a certain rating signifies an opposite result. Another option is to answer "not available" (n.a), which can be used when there is no available data or the answer cannot be quantified. Table 5 illustrates the structure of the model suggested:

The qualitative outcomes ranging from "Excellent" to "Terrible" follow the references of the SICOGEA third generation, as indicated in Table 6. That is, the respondents insert their information in the model, which in turn calculates the "degree" of effectiveness from the STIs concerning the questions asked:

With the data in hand, the SEIF/STI requires researchers to attribute values, or "possible scores" to the questions to settle a metric of relevance for each question. According to Pfitscher's (2009 apud Pieri et al., 2011) definition, these values represent the researcher's judgment, so that the author recommends the regulation of the procedure to avoid deviations that might undermine the work, that is, the author suggests the establishment of a standard range to attribute weights, so a certain degree of compatibility and comparison between the categories can be maintained.

SICOGEA third generation outlines this standard scale and indicates the reference figures (from 0 to 3 ), linking with the following qualitative relation to the sustainability result: 
Table 3

Steps for the Sustainability Evaluation International Framework applied to Science and Technology Institutes - SEIF/STI.

\begin{tabular}{|c|c|c|c|}
\hline Steps & \multicolumn{2}{|l|}{ Performance indexes } & Features considered \\
\hline STEP 01 & \multirow{2}{*}{\multicolumn{2}{|c|}{$\begin{array}{l}\text { Economic (GRI-G4) } \\
\text { Environmental (GRI-G4) }\end{array}$}} & Economic performance; presence in the market; indirect economic impacts; purchase practices. \\
\hline STEP 02 & & & $\begin{array}{l}\text { Materials; energy; water; biodiversity; emissions; effluents and waste; products and services; } \\
\text { conformity; general; suppliers environmental evaluation; mechanisms of complaints related to } \\
\text { environmental impacts. }\end{array}$ \\
\hline \multirow[t]{6}{*}{ STEP 03} & \multirow[t]{6}{*}{ Social/institutional } & $\begin{array}{l}\text { Labor practices and decent } \\
\text { work (GRI-G4) }\end{array}$ & $\begin{array}{l}\text { Labor; labor relations; labor health and safety; training and education; diversity and equal } \\
\text { opportunities; equal salary rights for men and women; evaluation of the suppliers in labor practices; } \\
\text { mechanisms of complaints related to labor practices. }\end{array}$ \\
\hline & & Human rights (GRI-G4) & $\begin{array}{l}\text { Investment; non-discrimination; freedom of association and collective bargaining; child labor; } \\
\text { forced or slave like labor; safety practices; native Brazilian rights; evaluation; evaluation of suppliers } \\
\text { in human rights; mechanisms of complaint related to human rights. . }\end{array}$ \\
\hline & & Society (GRI-G4) & $\begin{array}{l}\text { Local communities; anti-corruption movements; public policies; additional disloyal competition; } \\
\text { conformity; evaluation of suppliers in impacts on the society; mechanisms of complaints related to } \\
\text { impacts on society. }\end{array}$ \\
\hline & & $\begin{array}{l}\text { Accountability for product/service } \\
\text { (GRI-G4) }\end{array}$ & $\begin{array}{l}\text { Customer's health and safety; product and service labeling; marketing communication; customer } \\
\text { privacy; conformity. }\end{array}$ \\
\hline & & Institutional (A3P) & $\begin{array}{l}\text { Rational use of natural resources/Combat waste; residue management; awareness and training; } \\
\text { quality of life in labor environment; and sustainable bids. }\end{array}$ \\
\hline & & Institutional (ISCN) & $\begin{array}{l}\text { Constructions and their sustainable impacts; planning in the campus and target; and integration of } \\
\text { the research, teaching, installations and extension. }\end{array}$ \\
\hline
\end{tabular}

Source: GRI, 2013b; ISCN, 2013; MMA - A3P, 2009.

Table 4

Questions formulated by SEIF/STI.

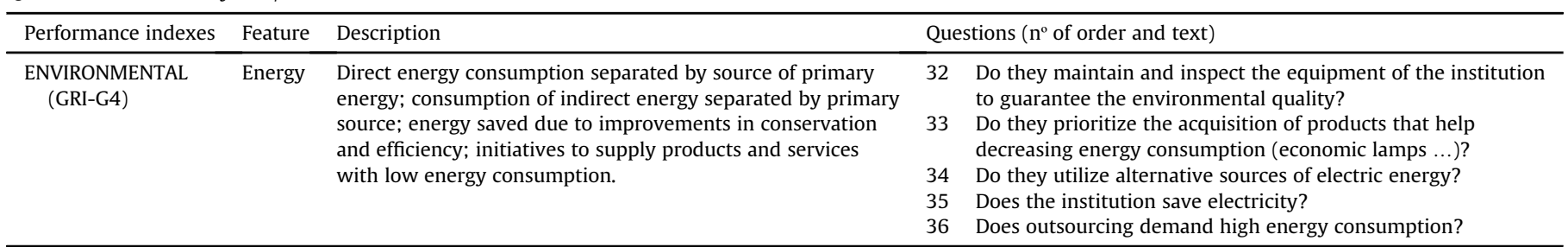

Source: GRI, 2013b.

Table 5

Sustainability Evaluation International Framework and Scientific and Technological Institutes Measurement.

\begin{tabular}{|c|c|c|c|c|c|c|c|c|c|c|c|c|c|c|}
\hline \multicolumn{2}{|c|}{ Questions } & \multirow[t]{2}{*}{ Inverse answer (S) } & \multirow{2}{*}{$\frac{0 \%}{0}$} & \multirow{2}{*}{$\frac{20 \%}{1}$} & \multirow{2}{*}{$\frac{40 \%}{2}$} & \multirow{2}{*}{$\frac{60 \%}{3}$} & \multirow{2}{*}{$\frac{80 \%}{4}$} & \multirow{2}{*}{$\frac{100 \%}{5}$} & \multirow{2}{*}{$\frac{-}{\mathrm{NA}}$} & \multirow[t]{2}{*}{ Possible scores } & \multirow[t]{2}{*}{ Score obtained } & \multirow[t]{2}{*}{ Total score } & \multicolumn{2}{|c|}{ Sustainability } \\
\hline & & & & & & & & & & & & & Result & Evaluation \\
\hline 1 & Question 15 & $\mathbf{S}$ & $\mathrm{X}$ & n.a & n.a & n.a & n.a & n.a & n.a & 1 & $0 \%$ & 1 & $100 \%$ & Excellent \\
\hline 2 & Question 16 & n.a & n.a & n.a & $\mathrm{X}$ & n.a & n.a & n.a & n.a & 1 & $40 \%$ & 0.4 & $40 \%$ & Weak \\
\hline 3 & Question 17 & n.a & n.a & n.a & n.a & $\mathrm{X}$ & n.a & n.a & n.a & 1 & $60 \%$ & 0.6 & $60 \%$ & Regular \\
\hline 4 & Question 18 & n.a & n.a & n.a & n.a & n.a & n.a & $\mathrm{X}$ & n.a & 3 & $100 \%$ & 3 & $100 \%$ & Excellent \\
\hline 5 & Question 19 & n.a & n.a & n.a & n.a & n.a & n.a & n.a & $\mathrm{X}$ & 3 & NA & 0 & $0 \%$ & - \\
\hline \multirow[t]{2}{*}{6} & Question 20 & n.a & n.a & $\mathrm{X}$ & n.a & n.a & n.a & n.a & n.a & 3 & $20 \%$ & 0.6 & $20 \%$ & Terrible \\
\hline & Sub-total & & 1 & 1 & 1 & 1 & 1 & 2 & 1 & 17 & $243 \%$ & 10 & $58.8 \%$ & Regular \\
\hline
\end{tabular}

Source: Pieri et al. (2011) and Pfitscher (2004).

These "possible weightings", as shown in Table 7, are confronted with the information of the respondents, resulting in a "score obtained", that is, the respondent's information ranked by the importance that research indicates to the existing situation. The result indicates in the "Sustainability > Evaluation" column a qualitative value (according to Table 6), corresponding to the SICOGEA - third generation's own methodology, with adaptations related to this research in particular, as described in Table 8:
From this, the Sustainability Evaluation International Framework applied to Science and Technology Institutes complies with its function of quantifying the qualitative responses, and eventually it indicates in which situations institutional deficiencies were verified that impair the sustainability or institutional advantages that contribute to the sustainability of the category analyzed.

With this model structure, the following sections evaluate the sustainability of several STIs through a hybrid of national and

Table 6

Possible performances.

\begin{tabular}{|c|c|c|}
\hline STI status & Degree & Score \\
\hline For the STI that presents no investment/control over the issue evaluated. & No & 0 or $0 \%$ \\
\hline For the STI that presents weak investment/control over the issue evaluated. & Weak & 1 or $20 \%$ \\
\hline For the STI that presents low investment/control, a little more than the item before, over the issue evaluated. & Low & 2 or $40 \%$ \\
\hline For the STI that d presents some investment/control, a little more than the item before, over the issue evaluated. & Some & 3 or $60 \%$ \\
\hline For the STI that presents strong investment/control, almost total, over the issue evaluated. & Strong & 4 or $80 \%$ \\
\hline For the STI that presents total high level investment/control over the issue evaluated. & High level & 5 or $100 \%$ \\
\hline
\end{tabular}

Source: Pieri et al. (2011) and Pfitscher (2004). 
Table 7

Possible weightings.

\begin{tabular}{|c|c|}
\hline Possible scores & Characteristic of the question \\
\hline 0 & Situation verified that neither impacts the environment nor influences much on the category under analysis. ${ }^{\text {a }}$ \\
\hline 1 & $\begin{array}{l}\text { Situation verified with low environmental impact and/or low social responsibility and/or low level of economic influence for } \\
\text { the category under analysis. }\end{array}$ \\
\hline 2 & $\begin{array}{l}\text { Situation verified with medium environmental impact and/or medium social responsibility and/or medium level of economic } \\
\text { influence for the category under analysis. }\end{array}$ \\
\hline 3 & $\begin{array}{l}\text { Situation verified with high environmental impact and/or high social responsibility and/or high level of economic influence for } \\
\text { the category under analysis. }\end{array}$ \\
\hline
\end{tabular}

a The categories are organized according to the steps of the framework, namely: Economic, Social and Environmental.

Source: Pieri et al. (2011) and Pfitscher (2004).

international guidelines (GRI, 2013b; ISCN, 2013; MMA - A3P, 2009), that is applied as a single methodology to measure STIs' contributions to sustainability.

\section{Results}

In this section, the authors evaluate two international Science and Technology Institutes: MIT - Massachusetts Institute of Technology, located in the United States and ETH-Zurich - Swiss Federal Institute of Technology Zurich, in Switzerland (Table 9).

The analysis was based on data collected from these institutions' official sites and from their official sustainability reports.

\subsection{International case study - MIT - Massachusetts Institute of Technology}

The Massachusetts Institute of Technology identifies as being dedicated to offering students an education that merges academic study with the support and intellectual encouragement of a diverse campus community (MIT, 2014).

MIT's internal concern with sustainability is evident from its Office of Sustainability at the nexus of the Institute's vice-chairman and treasurer's office. Some of the office's responsibilities include:

Assure that the growth, development and modernization of the campus reflect the highest commitment with the sustainability, to demonstrate the leadership practices and advance in the search for innovation; Incorporate the principles of sustainability in all operational functions of the Institute and promote global systems adapted to continuous improvement; Search for shared solutions for the common challenges with the cities of Cambridge, Boston and close partners; Qualify the campus as a laboratory of life apprenticeship for sustainability, which brings new knowledge and support action (Office of Sustainability MIT, 2014).

According to Lukman et al. (2009, p. 639) 'Assessing the environmental impacts of universities is not a trivial task due to the complexity and diversity of their operations. Nevertheless, it is deemed important to estimate these in order to identify more sustainable options for reducing their environmental footprints.' On the other hand, Eriksson et al. (2015, p. 331) argues that 'the rate of use of campus facilities is often very low - this creates wide sustainability potential and need for innovations and development - in terms of retrofitting and sustainability it is an important opportunity.' In this way, trying to catalyze the changes in the Institute as a whole, the campus is described as a true experiment for new practices concerning sustainability, and disseminates to all students and professors Institute's best practices in an integrated way, with a visionary adoption of future strategies.

\subsubsection{Document analysis - MIT/USA}

The SEIF/STI data analysis verified that MIT has implemented many internal policies concerning sustainability in all three (economic, environmental and social) dimensions, which were thoroughly discussed and disseminated into the Science and Technology Institutes, indicating an international regime of sustainability in formation.

This analysis takes as its base the final value of the sustainability index of the Sustainability Evaluation International Framework applied to Science and Technology Institutes for this specific case, which evaluates the sustainability practices of the Institute as "Excellent" (84.5\%). Considering the methodology applied for MIT, the social dimension appears to be relevant, demonstrating the higher performance index collected by the SEIF/STI, also as "Excellent" (88.3\%), showing that the Institute "presents a high level of total investment/control" related with the social theme and its evaluated aspects.

The high scores of the practices of sustainability in the three dimensions as indicated by the SEIF/STI confirms that the Institute is, for the standards internationally disseminated through tools such as GRI and ISCN, capable of predicting damage and warning collaborators and students toward the necessity of sustainable attitudes.

Among MIT's most important actions are those concerning the core element of their analysis, which makes it a reference for this study. In qualitative terms, in the index's economic rating (63.6\%) it is possible to observe that the Institute's total concern with suppliers can be expanded so as to predict the costs and damages related to the supply of raw material or service.

On the other hand, the Institute is mindful of its physical spaces and has a low impact on the environment. However, there is a limiting factor: MIT, in its publication and data provided to the public, it does not directly outline the treatment of or relation to its suppliers from outside of its campus. This shows that the institution does not demonstrate sufficient oversight of outsourced raw material and equipment supplier services.

According to Table 9, it was possible to observe from the data collected, that the framework considers MIT "Excellent" in its grand total, scoring $84.5 \%$ for performance, to a great extent triggered by the index's social component (88.3\%), which is highlighted, as detailed in Table 10. The Human Rights subcategory also greatly influences the result, especially in the GRI categories of Investments, Non-discrimination and Freedom of Association and Collective Bargaining.

Table 10 indicates the number of answers compared to the total, with values ranging from 0 to 5 . It is possible to observe the highest number of answers obtained, emphasizing and prioritizing certain areas over others:

A high number of answers (56\%) for the economic dimension are not available, which may suggest a lack of transparency regarding third-party suppliers, since there was not readily available information in the reports under analysis. 
Table 8

SEIF/STI possible performances.

\begin{tabular}{|c|c|c|}
\hline Result & Sustainability & Performance (control, incentive, strategy) \\
\hline Under $20 \%$ & “Terrible" & There is not practical institutional concern; great negative impact is caused on the category under analysis. \\
\hline Between $20.01 \%$ and $40 \%$ & "Weak" & There is damage for the sustainability of the category under analysis, but there are few positive initiatives. \\
\hline Between $40.01 \%$ and $60 \%$ & “Regular” & The sustainability legislation is attended concerning the category under analysis \\
\hline Between $60.01 \%$ and $80 \%$ & “Good" & $\begin{array}{l}\text { Legislation is not the only concern; there are projects and internal attitudes that aim to value the concern } \\
\text { with the category under analysis. }\end{array}$ \\
\hline Over $80 \%$ & "Excellent" & $\begin{array}{l}\text { High appreciation of the category under analysis, in the sense of predicting damage and making participants } \\
\text { aware of sustainable conducts. }\end{array}$ \\
\hline
\end{tabular}

Source: Pieri et al. (2011) and Pfitscher (2004).

Table 9

Comparative performance indexes.

\begin{tabular}{|c|c|c|c|c|c|c|}
\hline \multirow[t]{3}{*}{ Performance indexes } & \multicolumn{2}{|c|}{ MIT/USA } & \multicolumn{2}{|c|}{ ETH/Zurich/Switzerland } & \multicolumn{2}{|c|}{ South region of Brazil } \\
\hline & \multicolumn{2}{|c|}{ Sustainability } & \multicolumn{2}{|c|}{ Sustainability } & \multicolumn{2}{|c|}{ Sustainability } \\
\hline & Result & Evaluation & Result & Evaluation & Result & Evaluation \\
\hline ECONOMIC (GRI-G4) & $63.6 \%$ & Good & $67.5 \%$ & Good & $64.8 \%$ & Good \\
\hline ENVIRONMENTAL (GRI-G4) & $77.6 \%$ & Good & $90.8 \%$ & Excellent & $55.7 \%$ & Regular \\
\hline SOCIAL/INSTITUTIONAL (GRI-G4, A3P, ISCN) & $88.3 \%$ & Excellent & 93.7\% & Excellent & $58.7 \%$ & Regular \\
\hline LABOR PRACTICES AND DECENT WORK & $88.1 \%$ & Excellent & $90.9 \%$ & Excellent & $68.8 \%$ & Good \\
\hline HUMAN RIGHTS & $96.9 \%$ & Excellent & $100 \%$ & Excellent & $66.3 \%$ & Good \\
\hline SOCIETY & $94.6 \%$ & Excellent & $96.7 \%$ & Excellent & $65.6 \%$ & Good \\
\hline ACCOUNTABILITY FOR THE PRODUCT & $94.3 \%$ & Excellent & $90.7 \%$ & Excellent & $84 \%$ & Excellent \\
\hline INSTITUTIONAL (A3P) & $87.6 \%$ & Excellent & $92.4 \%$ & Excellent & $52.4 \%$ & Regular \\
\hline INSTITUTIONAL (ISCN) & $83.1 \%$ & Excellent & $94.7 \%$ & Excellent & $46.3 \%$ & Regular \\
\hline STI grand total & $84.5 \%$ & Excellent & 92.1\% & Excellent & $58 \%$ & Regular \\
\hline
\end{tabular}

Nevertheless, the potential performance rise in the "Institutional (ISCN, 2013)" social subcategory could be explored. By the analysis extracted from the SEIF/STI, it shows that the Institute can prioritize actions related to the consumption of energy in shared physical spaces such as classrooms and restrooms, as well as through campaigns for consumption awareness among students, faculty and staff.

Some new features and trends of energy system have emerged in the last decade, for example, solar energy systems for building integration, renewable energy source heat pumps, high efficiency cogeneration system, etc. These growing technologies are encouraged by governments to save fossil fuel and to keep a sustainable development for human society (Deng et al., 2011, p. 152).

The numbers also show that there are spaces yet to be conquered, as is the case with the environmental arena (77.6\%), mainly in the categories linked to "Materials" and "Water". Nonetheless, there are significant improvements, as innovative initiatives in the transportation areas on the campus concerning emission reduction, through the use of bicycles and electric vehicles, and the awareness and qualification of the collaborators, with a great quantity of sustainability educational initiatives in and out of the classroom implemented and divulged by the institutional channels of the MIT. According to Balsas (2003, p. 36), '[...] due to their pro-active educational milieu, college campuses are privileged places to communicate sustainability and to help reshape society's transportation patterns.'

The initiatives described in MIT's Sustainability Report, besides the additional information collected from its institutional electronic addresses, corroborate the institutions adherence to the preeminent international sustainability norms and procedures. The ratings of "good" or "excellent" describe $62.3 \%$ of the total categories under review, showing a high level of concern from the Institute towards sustainability in its most diverse dimensions.

\subsection{International case study - Eth-Zurich - Swiss Federal Institute of Technology Zurich}

For ETH Zurich, the theme of sustainability is integrated in the institute's research, teaching and operations, making the theme an important element of university life. The Coordinating Office for Sustainability (Sustainability/ETH, 2014) is the internal organ responsible for information concerning the issues, and since its

Table 10

Performance indexes - MIT/USA concentration of questions.

\begin{tabular}{|c|c|c|c|c|c|c|c|}
\hline \multirow[t]{2}{*}{ Performance indexes } & \multirow{2}{*}{$\frac{0 \%}{0}$} & \multirow{2}{*}{$\frac{20 \%}{1}$} & \multirow{2}{*}{$\frac{40 \%}{2}$} & \multirow{2}{*}{$\frac{60 \%}{3}$} & \multirow{2}{*}{$\frac{80 \%}{4}$} & \multirow{2}{*}{$\frac{100 \%}{5}$} & \multirow{2}{*}{$\frac{-}{\mathrm{NA}}$} \\
\hline & & & & & & & \\
\hline ECONOMIC (GRI-G4) & $4 \%$ & $4 \%$ & $16 \%$ & $16 \%$ & $0 \%$ & $4 \%$ & $56 \%$ \\
\hline ENVIRONMENTAL (GRI-G4) & $1 \%$ & $1 \%$ & $5.2 \%$ & $22.7 \%$ & $21.7 \%$ & $33 \%$ & $15.5 \%$ \\
\hline SOCIAL/INSTITUTIONAL (GRI-G4, A3P, ISCN) & $0 \%$ & $0 \%$ & $1.7 \%$ & $7.9 \%$ & $48.9 \%$ & $48.9 \%$ & $15.7 \%$ \\
\hline LABOR PRACTICES AND DECENT WORK & $0 \%$ & $0 \%$ & $0 \%$ & $7.3 \%$ & $41.5 \%$ & 41.5\% & $22 \%$ \\
\hline HUMAN RIGHTS & $0 \%$ & $0 \%$ & $0 \%$ & $0 \%$ & $10.5 \%$ & $\mathbf{5 7 . 9 \%}$ & $31.6 \%$ \\
\hline SOCIETY & $0 \%$ & $0 \%$ & $7.7 \%$ & $0 \%$ & $19.2 \%$ & $61.5 \%$ & $11.5 \%$ \\
\hline ACCOUNTABILITY FOR THE PRODUCT & $0 \%$ & $0 \%$ & $0 \%$ & $6.7 \%$ & $13.3 \%$ & $73.3 \%$ & $6.7 \%$ \\
\hline INSTITUTIONAL (A3P) & $0 \%$ & $0 \%$ & $2.8 \%$ & $11.1 \%$ & $19.4 \%$ & $47.2 \%$ & $19.4 \%$ \\
\hline INSTITUTIONAL (ISCN) & $0 \%$ & $0 \%$ & $0 \%$ & $14.6 \%$ & $43.9 \%$ & $36.6 \%$ & $4.9 \%$ \\
\hline STI grand total & $0.7 \%$ & $0.7 \%$ & $4 \%$ & $13.3 \%$ & $22.3 \%$ & $40 \%$ & $19 \%$ \\
\hline
\end{tabular}


creation in 2008 it supports initiatives that contribute to improving the Institute's sustainability.

Educational campuses are a part of the urban ecosystem. It is important to gauge various activities within a higher educational campuses with regard to sustainability, within the immediate environ-the campus, so that they may be groomed to shoulder the responsibility towards achieving a sustainable environment (Bantanur et al., 2015, p. 323).

As a coordinating center, ETH Sustainability took its position directly subordinate to the Institute's President in 2008 and works to connect and consolidate the several sustainability activities of ETH Zurich, in a way such that the visibility of the Institute's sustainability initiatives is enhanced internally and externally (Sustainability/ETH, 2014).

\subsubsection{Document analysis - ETH-Zurich}

The data analyzed by the SEIF/STI, show that the ETH-Zurich has the highest grade of implementation of internal policies related to sustainability in all three (economic, environmental and social) dimensions (ETH, 2014). From the measures the STIs discussed and disseminated, indicating an international regime of sustainability in formation, ETH-Zurich presents the highest relative performance.

The analysis in this case is based on the final value of the sustainability index of the SEIF/STI. The Institute's sustainability practices are evaluated as "Excellent" (92.1\%). Through the methodology applied to MIT, the great relevance of social dimensions is evident, presenting the highest performance index collected by the SEIF/STI, a rating of "Excellent" (93.6\%), indicating that the Institute presents a "high level of total investment/control" concerning social themes. However, it is important to emphasize that the environmental dimension contributed largely to the global performance that SEIF/STI measured, since the ETH-Zurich presents "Excellent" performance (90.7\%) in this item too.

As with MIT, the high value given to the sustainability practices in the three dimensions, as indicated by the SEIF/STI, shows that the Institute is, for the international standards given by tools such as the GRI and ISCN, capable of predicting damage and warning the collaborators and students about the need for sustainable attitudes, emphasizing, in this case, the composition of the "excellent" environmental rating, almost the same as the one expressed by the social/institutional dimension.

Among the most important actions of ETH-Zurich are those related to the core elements of the analysis of the Institute (social/ institutional and environmental), which makes it a reference for this study, mainly when compared to the other cases analyzed (MIT, and, in the next section, the Brazilian South). Qualitatively, the economic rating (67.5\%) presents the same situation concerning suppliers that were already observed for MIT, highlighting the lack of data concerning the treatment given to the control of suppliers. Additionally, the ETH-Zurich is more limited financially than its North American peer, since a large share (about 75\%) of its funding comes from the Swiss government (Sustainability/ETH, 2014).

As shown in Table 9, the total evaluation of ETH-Zurich is considered "Excellent", with $92.1 \%$ in performance, mostly triggered by the social dimension (93.7\%), which is highlighted, as detailed in Table 9, by the subcategory that takes into account the Institution's respect for Human Rights, especially in the same GRI outstanding categories for MIT, namely Investments, Nondiscrimination and Freedom of association and collective bargaining. It is worth mentioning that their concern is such that ETHZurich develops guidebooks to combat discrimination based on sexual orientation, race and ethnicity among students, with panels and pamphlets spread across campus.
Table 11 shows the number of answers in comparison with the total, with values ranging from 0 to 5 . In this way it is possible to observe the highest number of responses, highlighting and prioritizing certain areas:

The responses for the economic dimension (36\%) are mostly not available, which suggest, as previously mentioned, a lack of transparency in dealings with third-party suppliers.

The authors are able to explore a potential improvement in performance in the environmental category, which accounts for $20.6 \%$ of the answers in the $80 \%$ range. This is a secondary analysis, considering that all categories (except for the economic, for the reasons presented above) show a concentration of "Excellent" ratings. From this SEIF/STI analysis, the data indicate that the Institute can prioritize actions related to the correct destination and use of recyclable and/or environmentally responsible materials, besides advancing in issues such as the mitigation of the environmental impacts of products and services, and the reach of the impact reduction.

Though there are opportunities for improvement - specifically for ETH-Zurich - such improvements would build on already implemented initiatives, such as the innovative initiatives on internal campus transportation by the use of bikes, the change from electric energy toward alternative sources of energy in several buildings, and initiatives concerning gender equality, occupational health improvements, nondiscrimination and reforestation in common campus areas.

Finally, it was observed that the initiatives described in ETHZurich's Reports of Sustainability, besides giving additional information collected from its institutional electronic addresses, indicate the corroboration of norms and procedures related to sustainability in an international context. Overall, $75.7 \%$ of the total questions in "good" or "excellent" show how concerned the Institute is about sustainability in all its dimensions, as shown in the tables and figures of this section.

\subsection{Evaluation of Brazilian STIs in Southern Brazil}

The STIs studied in this research are part of a federal network of professional, scientific and technological education that covers all Brazilian states. These Institutes, which are managed under the Ministry of Education (MEC), offer technical, higher education, bachelor, master and $\mathrm{PhD}$ degrees around the country (RFEPT, 2014). For this research, three Institutes linked to the federal network are analyzed: IFSC (2014), IFPR (2014) and IFRS (2014), all in the southern region of Brazil.

\subsubsection{Analyses from the Southern region of Brazil}

This work will approach the quantitative results found by the SEIF/STI when applied to the South Region of Brazil. The analyses were conducted based on online questionnaires. The SEIF/STI's questions were divided to encourage responses. In all, 58 responses were collected from the Federal Institutes in each of the following categories:

After the compilation of the information for each of the Institutes' responses presented in Table 12, the weighted mean of the responses is calculated, except where results are not available. For example, for the 18 respondents on economic performance, the authors adopted a weighted average of the responses such that there is just one number expressing the set of responses for one question. This weighted average was included in the SEIF/STI and is analyzed in this section.

The data collected showed that the STIs of Brazil's southern region "only just obey the sustainability legislation" for the environmental and social dimensions, as well as for its general performance. From the measures that were largely discussed and 
Table 11

Performance indexes - concentration of questions ETH-Zurich.

\begin{tabular}{|c|c|c|c|c|c|c|c|}
\hline \multirow[t]{2}{*}{ Performance indexes } & \multirow{2}{*}{$\frac{0 \%}{0}$} & \multirow{2}{*}{$\frac{20 \%}{1}$} & \multirow{2}{*}{$\frac{40 \%}{2}$} & \multirow{2}{*}{$\frac{60 \%}{3}$} & \multirow{2}{*}{$\frac{80 \%}{4}$} & \multirow{2}{*}{$\frac{100 \%}{5}$} & \multirow{2}{*}{$\frac{-}{\mathrm{NA}}$} \\
\hline & & & & & & & \\
\hline ECONOMIC (GRI-G4) & $4 \%$ & $8 \%$ & $4 \%$ & $12 \%$ & $12 \%$ & $24 \%$ & $36 \%$ \\
\hline ENVIRONMENTAL (GRI-G4) & $0 \%$ & $0 \%$ & $0 \%$ & $1 \%$ & $20.6 \%$ & $56.7 \%$ & $21.7 \%$ \\
\hline SOCIAL/INSTITUTIONAL (GRI-G4, A3P, ISCN) & $0 \%$ & $0.6 \%$ & $0.6 \%$ & $7.3 \%$ & $10.1 \%$ & $70.4 \%$ & $11.2 \%$ \\
\hline LABOR PRACTICES AND DECENT WORK & $0 \%$ & $2.4 \%$ & $2.4 \%$ & $0 \%$ & $14.6 \%$ & $65.9 \%$ & $14.6 \%$ \\
\hline HUMAN RIGHTS & $0 \%$ & $0 \%$ & $0 \%$ & $0 \%$ & $0 \%$ & $63.2 \%$ & $36.8 \%$ \\
\hline SOCIETY & $0 \%$ & $0 \%$ & $0 \%$ & $11.5 \%$ & $11.5 \%$ & $73.1 \%$ & $3.9 \%$ \\
\hline ACCOUNTABILITY FOR THE PRODUCT & $0 \%$ & $0 \%$ & $0 \%$ & $13.3 \%$ & $20 \%$ & $66.7 \%$ & $0 \%$ \\
\hline INSTITUTIONAL (A3P) & $0 \%$ & $0 \%$ & $0 \%$ & $13.5 \%$ & $8.1 \%$ & $70.3 \%$ & $8.1 \%$ \\
\hline INSTITUTIONAL (ISCN) & $0 \%$ & $0 \%$ & $0 \%$ & $7.3 \%$ & $7.3 \%$ & $78.1 \%$ & $7.3 \%$ \\
\hline STI-ETH grand total & $0.3 \%$ & $1 \%$ & $0.7 \%$ & $5.7 \%$ & $13.6 \%$ & $62.1 \%$ & $16.6 \%$ \\
\hline
\end{tabular}

disseminated by the STIs involved and that indicate an international regime of sustainability in formation, STIs in the south of Brazil present the least relative performance, as evidenced in this section.

This analysis takes as its base the final value of the sustainability index of the SEIF/STI for this case, which evaluates the sustainability practices of the STIs of the Brazilian South as "regular" (58\%). By the methodology applied, the STIs of the Brazilian South present great relevance in the economic dimension, showing a categorization of "good" (64.8\%), the highest performance index collected by the SEIF/ STI, indicating that the Institutes "show an average level of the total investment/control" concerning the economic dimension and the features evaluated. It is interesting to observe that the number for the environmental and the social/institutional dimensions are quite close to each other, since they indicate, respectively, performances classified as "regular", but with percentages of $55.6 \%$ and $58.6 \%$.

This lesser performance of the STIs in the Brazilian South, when demonstrating an average assessment of the sustainability practices in the three dimensions, as indicated by the SEIF/STI, shows that the region is less capable, according to the international standards divulged by the GRI and ISCN tools, of predicting damage and warning their collaborators and students about the necessity of sustainable attitudes, and in particular, that the region is limited in its adherence to sustainability legislation.

In qualitative terms, in their average economic rating $(64.80 \%)$ these Institutes differ from the other cases (MIT and ETH-Zurich) precisely because it is possible to obtain responses concerning their suppliers. They also show that they have a "weak" performance when compared to better performances in the control of indirect economic impacts originating from infrastructure investments and services offered.

The STIs in the Brazilian South therefore do not present high impact on the environment, but instead present financial sustainability, in the sense that they guarantee higher education services without prejudice to intermediate activities - and compared to the ETH-Zurich, do not indicate budget constraints, since the responses in the survey indicated recent growth of their budgets. This indicates, from a financial point of view, that budgetary security that the Brazilian federal government affords these institutions allows these STIs a greater degree of economic sustainability.

The environmental dimension presents potential for improvement, since it shows the worst performance of the group, triggered by the "Water", "Energy" and "Emissions" categories. For this, the Institutes must create initiatives to combat resource waste, besides introducing new forms of treatment for residues and emissions.

Table 13 presents the amount of responses compared to its total, with values ranging from 0 to 5 . In this way, it is possible to observe where the highest number of responses obtained is, highlighting and prioritizing certain areas in comparison to others:

As evident from Table 13, the authors were able to explore the possibility of improving the performance in both the environmental and social/institutional dimensions, which show low response values of $60 \%$. A major problem when trying to improve the sustainability performance in HEIs, is the way in which they were built, as the physical development planning of the campuses are not well planned (Abd-Razak et al., 2011).

Table 12

Federal Institute's respondents.

\begin{tabular}{|c|c|c|c|}
\hline $\begin{array}{l}\text { Economic performance } \\
\text { (18 responses) }\end{array}$ & $\begin{array}{l}\text { Environmental performance } \\
\text { (15 responses) }\end{array}$ & $\begin{array}{l}\text { Social performance }- \text { GRI } \\
\text { (14 responses) }\end{array}$ & $\begin{array}{l}\text { Social performance }-\mathrm{A} 3 \mathrm{P} / \mathrm{ISCN} \\
\text { (11 responses) }\end{array}$ \\
\hline $\begin{array}{l}\text { IFPR - Cascavel } \\
\text { IFPR - Jacarezinho } \\
\text { IFPR - Palmas } \\
\text { IFRS - Bento Gonçalves } \\
\text { IFRS - Caxias do Sul } \\
\text { IFRS - Feliz } \\
\text { IFRS - Osório } \\
\text { IFRS - Restinga } \\
\text { IFRS - Sertão } \\
\text { IFSC - Caçador } \\
\text { IFSC - Chapecó } \\
\text { IFSC - Criciúma } \\
\text { IFSC - Gaspar } \\
\text { IFSC - Joinville } \\
\text { IFSC - São Carlos } \\
\text { IFSC - São José } \\
\text { IFSC - São Miguel do Oeste } \\
\text { IFSC - Xanxerê }\end{array}$ & $\begin{array}{l}\text { IFPR - Foz do Iguaçu } \\
\text { IFPR - Palmas } \\
\text { IFRS - Bento Gonçalves } \\
\text { IFRS - Caxias do Sul } \\
\text { IFRS - Feliz } \\
\text { IFRS - Osório } \\
\text { IFRS - Restinga } \\
\text { IFRS - Sertão } \\
\text { IFSC - Chapecó } \\
\text { IFSC - Florianópolis-Continente } \\
\text { IFSC - Gaspar } \\
\text { IFSC - Joinville } \\
\text { IFSC - São Carlos } \\
\text { IFSC - São José } \\
\text { IFSC - Xanxerê }\end{array}$ & $\begin{array}{l}\text { IFPR - Foz do Iguaçu } \\
\text { IFPR - Jacarezinho } \\
\text { IFPR - Palmas } \\
\text { IFRS - Bento Gonçalves } \\
\text { IFRS - Caxias do Sul } \\
\text { IFRS - Feliz } \\
\text { IFRS - Osório } \\
\text { IFRS - Restinga } \\
\text { IFSC - Chapecó } \\
\text { IFSC - Gaspar } \\
\text { IFSC - São Carlos } \\
\text { IFSC - São José } \\
\text { IFSC - São Miguel do Oeste } \\
\text { IFSC - Xanxerê }\end{array}$ & $\begin{array}{l}\text { IFPR - Curitiba } \\
\text { IFPR - Palmas } \\
\text { IFRS - Bento Gonçalves } \\
\text { IFRS - Caxias do Sul } \\
\text { IFRS - Feliz } \\
\text { IFRS - Osório } \\
\text { IFRS - Restinga } \\
\text { IFSC - Chapecó } \\
\text { IFSC - São Carlos } \\
\text { IFSC - São José } \\
\text { IFSC - Xanxerê }\end{array}$ \\
\hline
\end{tabular}


From this SEIF/STI analysis the authors consider how far from excellent the South Region is, according to the A3P and ISCN criteria, since the responses for those indexes are concentrated in "regular" (60\%), showing unimpressive values in "good" (80\%) and no response in "excellent" (100\%).

It should be mentioned that there is more to accomplish, but it is notable that the general index for the sustainability of the STIs in the Brazilian South is $58 \%$, despite the distance from international networks that more strongly disseminate the norms and procedures of a sustainability regime. Although the numbers indicate progress, it is fundamental to progress in areas that can improve the indexes, mainly in the environmental and social/institutional dimensions, giving special attention to the latter concerning the indexes related to the ISCN and A3P.

Finally, the STIs of the South Region of Brazil also show a corroboration of norms and procedures regarding sustainability in an international sense, even though they are not thoroughly integrated with global concerns, disseminated through an international regime of sustainability. The evaluations of "good" or "excellent" categories, in this case, make up $28.5 \%$ of all the questions. Aside from this low number, the Brazilian South generally presents data confirming that the institutions operate, with some regularity, in a manner that is internationally recognized within the theme of sustainability.

\section{Discussion}

Sustainability has been a core concern of international discussions in recent decades, as expressed recently by the new President of the United Nations General Assembly, Mr. Sam Kahamba Kutesa, in his inaugural speech during the 69th UN General Assembly on September 16, 2014. In that speech, he said "we also have a historic opportunity to formulate a post-2015 development agenda that is transformative, brings tangible benefits, leads to improved livelihoods for all, and contributes to achieving sustainable development in its social, economic and environmental dimensions" (United Nations, 2014).

It is in this same direction that the internationalization of sustainability themes spread the necessity of natural resource management in STIs within and outside of Brazil, since those are considered to be the house of future professionals and leaders of the society (Saadatian et al., 2011). The trend towards international networks begins, in this way, to improve the capacity of Science and Technology Institutes to enhance the practices that promote sustainability in those three dimensions. In this same train of thought, assessment tools and frameworks end up serving as a guide to the activities of HEIs (Yarime and Tanaka, 2012).

In this way, this research has aimed at uncovering to what extent STIs are contributing to the spread of sustainable practices, and could quantitatively indicate the extent of their contributions through a sustainability evaluation framework (SEIF/STI). Moreover, it is important to highlight that this study makes a comparative evaluation between the STIs, which is also an advance in the field. Although many papers developed their own methods of assessment, there was still a gap in this aspect of comparison.

The results of the survey show that sustainability is disseminated by the STIs involved and considers the result that, to a great extent, the internationally shared guidelines are met by the international STIs, whereas the Brazilian STIs comply with only a little more than half of those same guidelines.

In numbers, the STIs contribute as follows: MIT indicates $84.5 \%$ compliance, according to the questions prepared by the SEIF/STI and applied to sustainability documents published by the institution.

ETH-Zurich indicates $92.1 \%$ of compliance to the same sustainability guidelines according to the SEIF/STI framework.

In the Brazilian case, among the 58 contributions from national STIs in the Brazilian South (IFSC, 2014; IFRS, 2014; IFPR, 2014), the same value corresponds to $58 \%$. That is to say, the national STIs presented $65.7 \%$ of the mean performance of the international STIs.

Although indicating different levels of adherence to each value, rule and procedure, the Brazilian STIs all contribute to an extent with the formation of an international sustainability regime, reaching over $50 \%$ for both the global indexes of the STIs (presented in the previous paragraph), and individual indexes of the social, environmental and economic dimensions. Brazilian STIs could use this research as a means of comparing their strengths and weaknesses with international STIs, and look practices used at MIT and ETH-Zurich to achieve better results.

Fig. 1 compares the percentages collected per dimension. The highlight is the distance between the social/institutional and the environmental dimensions of the Brazilian South when compared to MIT and ETH-Zurich, which is different from what is observed in the economic ratings:

As seen in Fig. 1, the total estimate of the foreign STIs leads the evaluations conducted by the SEIF/STI. This is partly due to the possibility of standardized data extraction through international sustainability reports published by the selected STIs. Nevertheless, we must consider that the leadership is expressed mainly by the content these foreign STIs can present regarding the actions developed toward sustainability in their activities. The reports that were analyzed indicate that there is a concrete action from the Institute for almost every aspect listed by the GRI and ISCN, and each action is largely divulged directly by institutions and via sustainability reports.

Another consideration indicates that the efforts of the STIs from the Brazilian South reach a little more than half of the performance of the foreign STIs, which are considered pioneers in the area of international sustainability norms and guidelines, since they

Table 13

Performance indexes - concentration of questions for the Brazilian south.

\begin{tabular}{|c|c|c|c|c|c|c|c|}
\hline \multirow[t]{2}{*}{ Performance indexes } & \multirow{2}{*}{$\frac{0 \%}{0}$} & \multirow{2}{*}{$\frac{20 \%}{1}$} & \multirow{2}{*}{$\frac{40 \%}{2}$} & \multirow{2}{*}{$\frac{60 \%}{3}$} & \multirow{2}{*}{$\frac{80 \%}{4}$} & \multirow{2}{*}{$\frac{100 \%}{5}$} & \multirow{2}{*}{$\frac{-}{\mathrm{NA}}$} \\
\hline & & & & & & & \\
\hline ECONOMIC (GRI-G4) & $0 \%$ & $20 \%$ & $20 \%$ & $24 \%$ & $4 \%$ & $32 \%$ & $0 \%$ \\
\hline ENVIRONMENTAL (GRI-G4) & $7.2 \%$ & $17.5 \%$ & $25.8 \%$ & $29.9 \%$ & $17.5 \%$ & $2.1 \%$ & $0 \%$ \\
\hline SOCIAL/INSTITUTIONAL (GRI-G4, A3P, ISCN) & $0 \%$ & $11.7 \%$ & $22.9 \%$ & $33 \%$ & $22.9 \%$ & $9.5 \%$ & $0 \%$ \\
\hline LABOR PRACTICES AND DECENT WORK & $0 \%$ & $7.3 \%$ & $19.5 \%$ & $22 \%$ & $31.7 \%$ & $19.5 \%$ & $0 \%$ \\
\hline HUMAN RIGHTS & $0 \%$ & $15.8 \%$ & $15.8 \%$ & $21.1 \%$ & $31.6 \%$ & $15.8 \%$ & $0 \%$ \\
\hline SOCIETY & $0 \%$ & $11.5 \%$ & $19.2 \%$ & $23.1 \%$ & $46.2 \%$ & $0 \%$ & $0 \%$ \\
\hline ACCOUNTABILITY FOR THE PRODUCT & $0 \%$ & $0 \%$ & $0 \%$ & $20 \%$ & $40 \%$ & $40 \%$ & $0 \%$ \\
\hline INSTITUTIONAL (A3P) & $0 \%$ & $5.4 \%$ & $32.4 \%$ & $56.8 \%$ & $5.4 \%$ & $0 \%$ & $0 \%$ \\
\hline INSTITUTIONAL (ISCN) & $0 \%$ & $24.4 \%$ & $31.7 \%$ & $39 \%$ & $4.9 \%$ & $0 \%$ & $0 \%$ \\
\hline STI grand total & $2.3 \%$ & $14.3 \%$ & $23.6 \%$ & $31.2 \%$ & $19.6 \%$ & $9 \%$ & $0 \%$ \\
\hline
\end{tabular}




\section{Sustainability Index - Dimensions}

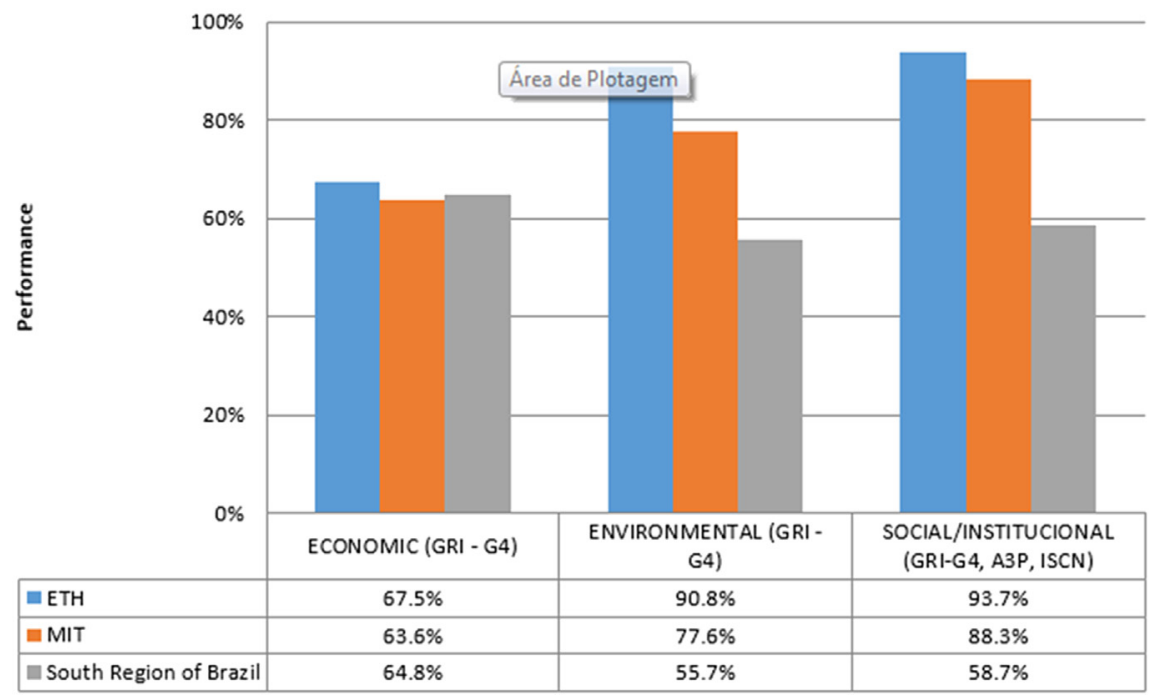

Fig. 1. Sustainability indexes.

occupy a space in international higher education networks that promotes the formation of an international sustainability regime through their practices.

The Brazilian South shows it is capable of succeeding, mainly in the environmental and social/institutional areas, by improving its current practices and maximizing joint efforts with other institutions. With regard to the economic dimension, the comparison of the three Brazilian STIs is jeopardized mainly by the impossibility of directly estimating the practices of suppliers in relation to the STIs. However, beyond that question, the situation between the STIs is well-adjusted, which demonstrates the great capacity of advancement in other areas, since the economic capacity of the STI is the driving force for the development of initiatives addressing the other two dimensions. "Limited funds challenge campus owners and operators to plan, design, construct, and operate sustainability improvement programs. One way to address this constraint is to use the sustainability program itself as a funding source for additional improvements" (Faghihi et al., 2015, p. 400).

The challenge facing the STIs in Southern Brazil lies in expanding the activities that are developed and disseminated effectively in their institutional websites or in specific reports. In questions such as "Do you know whether the institution uses a Social Balance?" or "Do you know whether the institution is familiar with the Social Balance structure?" the responses for the Brazilian South register 20\%, a percentage that, in the methodology applied by the SEIF/STI, indicates a categorization of "terrible", suggesting practical institutional disregard to the observed theme.

In dealing specifically with the social/institutional dimension, it is also possible to establish the comparison from Fig. 2:

From this SEIF/STI analysis, it is understandable that the essential advances for the Brazilian South in the social/institutional dimension are centered in the "Institutional A3P" and "Institutional ISCN" subcategories. While in the first, the necessity of participation of STIs is highlighted in the processes of "Awareness and Capacitation" and "Quality of life in the work environment", for the improvement of the second subcategory, institutional attention to short-term courses related to sustainability is necessary, among other measures, in addressing students, faculty and staff. These can be understood as complementary or communicative measures.

As stated in the literature review session, cross-institutional assessment tools are essential so that STIs could paint a better picture of what could be done differently to achieve sustainable practices. Unfortunately, for that to happen, these institutions need to be willing to efficiently report their activities so that the evaluation could be more accurate. HEIs serve as a model on the spread of sustainable practices and if so, they need to be aware of their contributions and limitations.

\section{Conclusions and recommendations for future research}

For quite some time, assessment tools have been used to measure sustainability within institutions. The need to adapt these tools to measure the sustainability of HEIs was soon realized, since campuses are small town-like communities, and these institutions can serve as a mirror for the dissemination of sustainable practices for the faculty, the student body and the surrounding community.

Thus, this research presents a breakthrough in the use of the most currently relevant international assessment tools methods (GRI, ISCN), combining them with a Brazilian tool based on national concern (A3P) and adapting them to the STIs.

The importance of the contribution of Science and Technology Institutes to creating participatory management in educational institutions, whether public or private, presents a great opportunity for changes in how society faces and solves problems of production and damage to the environment. The contributions of STIs to sustainability were verified through an evaluation framework for sustainability, the deepening of practices that monitor socioeconomic-environmental issues on the institutional management level. This monitoring includes activities that reveal the identification and application of procedures that facilitate the diffusion and further development of select practices promoted by these STIs.

In addition, the investigation of tools such as GRI contribute to the analysis of which the main guidelines are grasp how different institutions interpret the concept of sustainability, and how the concept is disseminated by the practices of institutions and other actors worldwide.

The literature review and the results of this survey reveal that HEIs are beginning to take actions and move efforts to engage in sustainable practices, and the use of evaluation frameworks seems to be one of the best methods to understand the institution's activities and how they can be improved. 


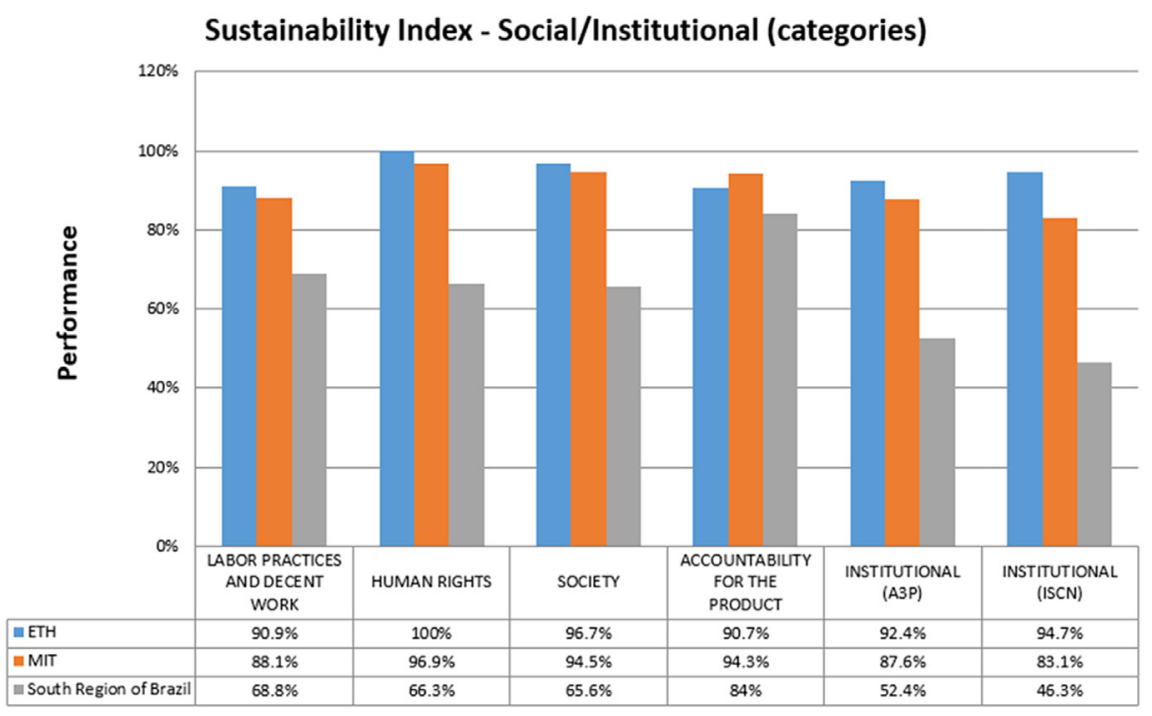

Fig. 2. Sustainability index - social/institutional (categories) comparison.

Therefore, this research achieves its purpose, using a unique method for the evaluation and comparison of STIs, encouraging more institutions to use this tool or adapt their own evaluation framework as needed.

One potential suggestion for further research on this subject is to replicate the SEIF/STI model among a greater number of STIs in Brazil and in other countries. Because the STIs under consideration in this study are limited to three countries, it is possible that certain aspects of each institution's rating are related to particular conditions in a country or climate. Assessing STIs in other countries within the same framework might better account for country differences and enable closer analysis and scrutiny of institutional practices at the university level.

Furthermore, it would be interesting for there to be participation from teachers from other STIs in future research, to bring sustainability understanding from broader perspectives. Finally, it would be productive for further work to enable onsite research and/or with the participation of different respondents (students, teachers and administrators/managers) in order to raise the awareness of all involved in the activities of STIs.

\section{Acknowledgments}

This study was supported by: Núcleo de Estudos sobre Meio Ambiente e Contabilidade (NEMAC), Programa Observatório da Educação (OBEDUC), Conselho Nacional de Desenvolvimento Cientifico e Tecnológico/Coordenação de Aperfeiçoamento de Pessoal de Nível Superior - (CNPQ/Capes) and the Energy Efficiency and Sustainability Research Group (Greens), from the University of Southern Santa Catarina (Unisul), in the context of the projects: Linkages between energy, food and water consumption in the context of climate change mitigation strategies (Links), and Building Resilience in a Dynamic Global Economy: Complexity across scales in the Brazilian Food-Water-Energy Nexus (Bridge), funded by the Newton Fund, Fundação de Amparo à Pesquisa e Inovação do Estado de Santa Catarina (FAPESC).

\section{List of acronyms}

A3P Public Administration Environmental Agenda ETH-Zurich Swiss Federal Institute of Technology Zurich GAIA Environmental Impact Aspects Management method
GRI Global Reporting Initiative

HEI Higher Education Institution

IFPR Federal Education, Science and Technology Institutes of Paraná

IFRS Federal Education, Science and Technology Institutes of Rio Grande do Sul

IFSC Federal Education, Science and Technology Institutes of Santa Catarina

ISCN International Sustainable Campus Network

MEC Ministry of Education

MIT Massachusetts Institute of Technology

SEIF/STI Sustainability Evaluation International Framework applied to Science and Technology Institutes

SICOGEA Environmental Management Accounting System

STIs Science and Technology Institutes

\section{Appendix A. Supplementary data}

Supplementary data related to this article can be found at http:// dx.doi.org/10.1016/j.jclepro.2016.03.028.

\section{References}

Abd-Razak, M.Z., Mustafa, N.K.F., Che-Ani, A.I., Abdullah, N.A.G., Mohd-Nor, M.F.I 2011. Campus sustainability: student's perception on campus physical development planning in Malaysia. Procedia Eng. 20, 230-237. http://dx.doi.org/ 10.1016/j.proeng.2011.11.160.

Alonso-Almeida, M.M., Marimon, F., Casani, F., Rodriguez-Pomeda, J., 2015. Diffusion of sustainability reporting in universities: current situation and future perspectives. J. Clean. Prod. 106, 144-154. http://dx.doi.org/10.1016/ j.jclepro.2014.02.008.

Alshuwaikhat, H.M., Abubakar, I., 2008. An integrated approach to achieving campus sustainability: assessment of the current campus environmental management practices. J. Clean. Prod. 16, 1777-1785. http://dx.doi.org/10.1016/ j.jclepro.2007.12.002.

Balsas, C.J.L., 2003. Sustainable transportation planning on college campuses Transp. Policy 10, 35-49. http://dx.doi.org/10.1016/S0967-070X(02)00028-8.

Bantanur, S., Mukherjee, M., Shankar, R., 2015. Emerging dimensions of sustainability in institutes of higher education in India. Int. J. Sustain. Built Environ. 4, 323-329. http://dx.doi.org/10.1016/j.ijsbe.2015.03.004.

Barth, M., 2013. Many roads lead to sustainability: a process-oriented analysis of change in higher education. Int. J. Sustain. High. Educ. 14, 160-175. http:// dx.doi.org/10.1108/14676371311312879.

Beynaghi, A., Moztarzadeh, F., Maknoon, R., Waas, T., Mozafari, M., Hugé, J., Leal Filho, W., 2014. Towards an orientation of higher education in the post Rio +20 process: how is the game changing? Futures 63, 49-67. http://dx.doi.org/ 10.1016/j.futures.2014.08.004 
Chambers, N., Simmons, C., Wackernagel, M., 2000. Sharing Nature's Interest: Ecological Footprints as an Indicator of Sustainability. Earthscan Publications Ltd., London.

Cole, L., May 2003. Assessing Sustainability on Canadian University Campuses: Development of a Campus Sustainability Assessment Framework. Thesis submitted in partial fulfillment of the requirements for the degree of Master of Arts in Environment and Management. Royal Roads University, p. 66. http:// neumann.hec.ca/humaniterre/campus_durable/campus_memoire.pdf.

Collins, F.L., 2010. International students as urban agents: international education and urban transformation in Auckland, New Zealand. Geoforum 41, 940-950. http://dx.doi.org/10.1016/j.geoforum.2010.06.009.

Cortese, A.D., 2003. The critical role of higher education in creating a sustainable future. Plan. High. Educ. 31, 15-22. http://www.aashe.org/resources/pdf/ Cortese_PHE.pdf.

de Ridder, W., Turnpenny, J., Nilsson, M., von Raggamby, A., 2007. A framework for tool selection and use in integrated assessment for sustainable development J. Environ. Assess. Policy Manag. 9, 423-441. http://www.pbl.nl/sites/default/ files/cms/publicaties/555030001.pdf.

de Vries, B.J.M., Petersen, A.C., 2009. Conceptualizing sustainable development: an assessment methodology connecting values, knowledge, worldviews and scenarios. Ecol. Econ. 68, 1006-1019. http://dx.doi.org/10.1016/ j.ecolecon.2008.11.015.

Deng, S., Dai, Y.J., Wang, R.Z., Zhai, X.Q., 2011. Case study of green energy system design for a multi-function building in campus. Sustain. Cities Soc. 1, 152-163. http://dx.doi.org/10.1016/j.scs.2011.07.002.

Domingues, A.R., Pires, S.M., Caeiroa, S., Ramos, T.B., 2015. Defining criteria and indicators for a sustainability label of local public services. Ecol. Indic. 57, 452-464. http://dx.doi.org/10.1016/j.ecolind.2015.05.016.

Elton, L., 2003. Dissemination of innovations in higher education: a change theory approach. Tert. Educ. Manag. 9, 199-214. http://dx.doi.org/10.1023/A: 1024472813449

Eriksson, R., Nenonen, S., Junghans, A., Nielsen, S.B., Lindahl, G., 2015. Nordic campus retrofitting concepts - scalable practices. Procedia Econ. Finance 21, 329-336. http://dx.doi.org/10.1016/S2212-5671(15)00184-7.

ETH. Swiss Federal Institute of Technology, 2014. The ETH Zurich. https://www.ethz ch/en/the-eth-zurich.html.

Faghihi, V., Hessami, A.R., Ford, D.N., 2015. Sustainable campus improvement program design using energy efficiency and conservation. J. Clean. Prod. 107, 400-409. http://dx.doi.org/10.1016/j.jclepro.2014.12.040.

Ferrer-Balas, D., Lozano, R., Huisingh, D., Buckland, H., Ysern, P., Zilahy, G., 2010 Going beyond the rhetoric: system-wide changes in universities for sustainable societies. J. Clean. Prod. 18, 607-610. http://dx.doi.org/10.1016/ j.jclepro.2009.12.009.

Figueiro, P.S., Raufflet, E., 2015. Sustainability in higher education: a systematic review with focus on management education. J. Clean. Prod. 106, 22-33. http:/ dx.doi.org/10.1016/j.jclepro.2015.04.118.

Gasparatos, A., Scolobig, A., 2012. Choosing the most appropriate sustainability assessment tool. Ecol. Econ. 80, 1-7. http://dx.doi.org/10.1016 j.ecolecon.2012.05.005.

GRI - Global Reporting Initiative, 2013b. Diretrizes para Relatos GRI. https://www. globalreporting.org/resourcelibrary/Brazilian-Portuguese-G4-Part-One.pdf.

GRI. Global Reporting Initiative, 2013a. https://www.globalreporting.org.

Hamann, R., 2003. Mining companies' role in sustainable development: the 'why' and 'how' of corporate social responsibility from a business perspective. Dev. South. Afr. 20, 234-254. http://dx.doi.org/10.1080/03768350302957.

Ho, Y., Chang, C., Wei, C., Wang, H., 2014. Multi-objective programming model for energy conservation and renewable energy structure of a low carbon campus. Energy Build. 80, 461-468. http://dx.doi.org/10.1016/j.enbuild.2014.04.054.

IFPR. Instituto Federal de Educação [Federal Institute of Education], 2014. Ciência e Tecnologia do Paraná (Science and Technology of Paraná). http://reitoria.ifpr. edu.br.

IFRS. Instituto Federal de Educação [Federal Institute of Education], 2014. Ciência e Tecnologia do Rio Grande do Sul (Science and Technology of Rio Grande do Sul). http://www.ifrs.edu.br//.

IFSC. Instituto Federal de Educação [Federal Institute of Education], 2014. Ciência Tecnologia de Santa Catarina (Science and Technology of Santa Catarina). http:/ www.ifsc.edu.br/menu-institucional.

ISCN. International Sustainable Campus Network, 2013. Working Groups. http:/ www.international-sustainable-campus-network.org/about/iscn-workinggroups.html.

Jannuzzi, P.M., 2008. Indicadores Sociais e as Políticas Públicas no Brasil (Social indicators and the public policy in Brazil). Rev. Com. Ciência 96. http://www. comciencia.br/comciencia/?section $=8$ \&edicao $=33 \& \mathrm{id}=386$.

Jenks-Jay, N., 2003. Cultivating a Shared Environmental Vision at Middlebury College. Project Kaleidoscope, p. 10. http://www.pkal.org/documents/middleburyshared-environmental-vision.pdf.

Katiliute, E., Daunoriene, A., Katkuté, J., 2014. Communicating the sustainability issues in higher education institutions World Wide Webs. Procedia Soc. Behav. Sci. 156, 106-110. http://dx.doi.org/10.1016/j.sbspro.2014.11.129.

Katiliute, E., Daunoriene, A., 2015. Dissemination of sustainable development on universities websites. Procedia Soc. Behav. Sci. 191, 865-871. http://dx.doi.org 10.1016/j.sbspro.2015.04.337.

Klein-Banai, C., Theis, T.L., 2013. Quantitative analysis of factors affecting greenhouse gas emissions at institutions of higher education. J. Clean. Prod. 48, 29-38. http://dx.doi.org/10.1016/j.jclepro.2011.06.004.
Lerípio, A.A., 2001. GAIA - Um Método de Gerenciamento de Aspectos e Impactos Ambientais (A Method of Managing Environmental Aspects and Impacts). UFSC Florianópolis. Thesis (Doutorado em Engenharia de Produção) Programa de PósGraduação em Contabilidade, Universidade Federal de Santa Catarina, Florianópolis. https://repositorio.ufsc.br/handle/123456789/81704.

Louette, A., 2007. Compêndio para a sustentabilidade: ferramentas de gestão de responsabilidade socioambiental-uma contribuição para o desenvolvimento sustentável (Compendium for Sustainability: Management Tools of Social and Environmental Responsibility, a Contribution to Sustainable Development). Antakarana Cultura Arte e Ciência, São Paulo, p. 75, 1. https://pactoglobalcreapr. files.wordpress.com/2010/10/compendio2008parte11.pdf.

Lozano, R., 2006. A tool for a graphical assessment of sustainability in universities (GASU). J. Clean. Prod. 14, 963-972. http://dx.doi.org/10.1016/ j.jclepro.2005.11.041.

Lozano, R., 2010. Diffusion of sustainable development in universities' curricula: an empirical example from Cardiff University. J. Clean. Prod. 18, 637-644. http:// dx.doi.org/10.1016/j.jclepro.2009.07.005.

Lozano, R., Huisingh, D., 2011. Inter-linking issues and dimensions in sustainability reporting. J. Clean. Prod. 19, 99-107. http://dx.doi.org/10.1016/j.jclepro.2010.01.004

Lozano, R Lukman, R Lozano, FJ. Huisingh, D Lambrechts, W., 2013. Declarations for sustainability in higher education: becoming better leaders, through addressing the university system. J. Clean. Prod. 48, 10-19. http://dx.doi.org/ 10.1016/j.jclepro.2011.10.006.

Lukman, R., Tiwary, A., Azapagic, A., 2009. Towards greening a university campus: the case of the University of Maribor, Slovenia. Resour. Conserv. Recycl. 53, 639-644. http://dx.doi.org/10.1016/j.resconrec.2009.04.014.

Menichini, T., Rosati, F., 2014. A fuzzy approach to improve CSR reporting: an application to the Global Reporting Initiative indicators. Procedia Soc. Behav. Sci. 109, 355-359. http://dx.doi.org/10.1016/j.sbspro.2013.12.471.

MIT. Massachusetts Institute of Technology, 2014. About MIT 2014. http://web.mit. edu/aboutmit/.

MMA - A3P, 2009. Ministério do Meio Ambiente, A3P - Agenda Ambiental na Administração Pública (Ministry of Environment - Environmental Agenda of Public Administration). http://www.mma.gov.br/estruturas/a3p/_arquivos/ cartilha_a3p_36.pdf.

Moldan, B., Janousková, S., Hák, T., 2012. How to understand and measure environmental sustainability: indicators and targets. Ecol. Indic. 17, 4-13. http:// dx.doi.org/10.1016/j.ecolind.2011.04.033.

Moldavska, A., Welo, T., 2015. On the applicability of sustainability assessment tools in manufacturing. Procedia CIRP 29, 621-626. http://dx.doi.org/10.1016/ j.procir.2015.02.203.

Ness, B., Urbel-Piirsalu, E., Anderberg, S., Olsson, L., 2007. Categorising tools for sustainability assessment. Ecol. Econ. 60, 498-508. http://dx.doi.org/10.1016/ j.ecolecon.2006.07.023.

Nourry, M., 2008. Measuring sustainable development: some empirical evidence for France from eight alternative indicators. Ecol. Econ. 67, 441-456. http:// dx.doi.org/10.1016/j.ecolecon.2007.12.019.

Nunes, J.P.O., 2010. Um aporte ao sistema contábil gerencial ambiental: elaboração e aplicação parcial do novo sistema em clínica hospitalar (A Contribution to Environmental Management Accounting System: Design and Partial Implementation of the New System in Clinical Hospital). Dissertação (Mestrado em Contabilidade), Programa de Pós-Graduação em Contabilidade. Universidade Federal de Santa Catarina, Florianópolis, p. 241. https://repositorio.ufsc.br/ handle/123456789/93622.

Office of Sustainability - MIT, 2014. Massachusetts Institute of Technology. https:// sustainability.mit.edu/.

Olszak, E., 2012. Composite indicators for a sustainable campus - design rationale and methodology: the case of the Catholic Institute of Lille. Ecol. Indic. 23, 573-577. http://dx.doi.org/10.1016/j.ecolind.2012.05.021.

Pfitscher, E.D., 2004. Gestão e sustentabilidade através da contabilidade e controladoria ambiental: estudo de caso na cadeia produtiva de arroz ecológico (Management and Sustainability Through Environmental Accounting and Controlling: a Case Study in the Supply Chain of Ecological Rice). Thesis (Doutorado em Engenharia de Produção). UFSC, Florianópolis, p. 252. http:// nemac.paginas.ufsc.br/files/2012/12/Tese-de-Doutorado-1-teseelisete.pdf.

Pieri, R., Pfitscher, E.D., Frey, I.A., Alberton, L., 2011. Gestão estratégica e ambiental: estudo de uma universidade comunitária (Strategic and environmental management: study of a Community College). In: XII Congresso Internacional de Costos, Punta del Este, Uruguay. Anais..., 2011.

Posner, S.M., Stuart, R., 2013. Understanding and advancing campus sustainability using a systems framework. Int. J. Sustain. High. Educ. 14, 264-277. http:// dx.doi.org/10.1108/IJSHE-08-2011-0055.

RFEPT, 2014. Rede Federal de Educação Profissional, Científica e Tecnológica (Federal Network of Vocational Education, Science and Technology). http:// redefederal.mec.gov.br/.

Rodenburg. E. 1995. Monitoring for sustainability a sustainable world: defining and measuring sustainable development. In: Trzyna, Thaddeus C. (Ed.), International Union for the Conservation of Nature, pp. 77-86.

Saadatian, O., Dola, K.B., Salleh, E.I., Tahir, O.M., 2011. Identifying strength and weakness of sustainable higher educational assessment approaches. Int. J. Bus. Soc. Sci. 2, 137-146. http://ijbssnet.com/journals/Vol._2_No._3_\%5BSpecial_ Issue_-_January_2011\%5D/16.pdf.

Sala, S., Ciuffo, B., Nijkamp, P., 2015. A systemic framework for sustainability assessment. Ecol. Econ. 119, 314-325. http://dx.doi.org/10.1016/ j.ecolecon.2015.09.015. 
Shriberg, M., 2002. Institutional assessment tools for sustainability in higher education: strengths, weaknesses, and implications for practice and theory. Int. J. Sustain. High. Educ. 3 (3), 254-270. http://dx.doi.org/10.1108/ 14676370210434714.

Sikka, P., 1998. Legal measures and tax incentives for encouraging science and technology development: the examples of Japan, Korea and India. Technol. Soc. 20, 45-60. http://dx.doi.org/10.1016/S0160-791X(97)00025-0.

Streimikiene, D., Girdzijauskas, S., Stoskus, L., 2009. Sustainability assessment methods and their application to harmonization of policies and sustainability monitoring. Environmental research. Eng. Manag. ISSN: 1392-1649 2, 51-62.

Sustainability/ETH, 2014. Swiss Federal Institute of Technology. https://www.ethz. ch/en/the-eth-zurich/sustainability/context.html.

Townsend, J., Barrett, J., 2015. Exploring the applications of carbon footprinting towards sustainability at a UK university: reporting and decision making. J. Clean. Prod. 107, 164-176. http://dx.doi.org/10.1016/j.jclepro.2013.11.004.

Uhlmann, V.O., 2011. Contribuições ao desenvolvimento do Sistema Contábil Gerencial Ambiental - Geração 2: Proposição da terceira geração do método (Contributions to the Development of Environmental Management Accounting System - 2nd Generation: Proposition of The Third Generation Method).
Dissertation (Mestrado em Contabilidade). Programa de Pós-Graduação em Contabilidade, Universidade Federal de Santa Catarina, Florianópolis, p. 113. https://repositorio.ufsc.br/handle/123456789/94709.

United Nations, 2014. General Assembly of the United Nations. http://www.un.org/ pga/statements/opening-69th-session/.

Van Bellen, Michael, H., 2006. Indicadores de sustentabilidade: uma análise comparative (Sustainability Indicators: a Comparative Analysis). FGV 2, Rio de Janeiro (RJ), ISBN 9788522505067, p. 253.

Velazquez, L., Munguia, N., Platt, A., Taddei, J., 2006. Sustainable university: what can be the matter? J. Clean. Prod. 14, 810-819. http://dx.doi.org/10.1016/ j.jclepro.2005.12.008.

Wilburn, K., Wilburn, R., 2013. Using global reporting initiative indicators for CSR programs. J. Glob. Responsib. 4, 62-75. http://dx.doi.org/10.1108/ 20412561311324078.

Yarime, M., Tanaka, Y., 2012. The issues and methodologies in sustainability assessment tools for higher education institutions: a review of recent trends and future challenges. J. Educ. Sustain. Dev. 6, 63-77. http://dx.doi.org/10.1177/ 097340821100600113. 